Mr. Hunter stated that the farmers in the section where his experiment was tried were anxious to have it repeated this year.

\title{
A LARGE SCALE EXPERIMENT IN THE CONTROL OF THE COTTON BOLL WEEVIL
}

By W. D. Hunter, Washington, D. C.

(Withdrawn for publication elsewhere.)

A paper was read as follows:

\section{THE ECONOMIC BEARING OF RECENT STUDIES OF THE PARASITES OF THE COTTON BOLL WEEVIL}

\author{
By W. D. PIerCe, Washington, D. $O$.
}

The utilization of parasites in the control of injurious insects generally has taken only the form of introduction from other localities or from foreign countries. Notable instances may be cited in the introduction of Scutellista cyanea from Africa into California to combat the black scale (Saissetia oleae), and the very recent introduction of this same parasite from California into Hawaii, there to attack a different species of scale in the same genus. The successful introduction of Rhogas lefroyi from southern India into the Punjab by Mr. Maxwell Lefroy in order to restore the former condition of control of the bollworm by this species, which was lilled out by the cold winter, and the more important fact that where introduced the parasites regained much of their former control is another example of the same kind. Mr. F. M. Webster, in a paper read before this association last winter, cited a number of important cases of valuable parasites in the control of cereal and grain crop insects.

Contrary to earlier suppositions, it is now apparent that parasites and predatory insects bear a very considerable part in the control of the boll weevil. It is important to note that the boll weevil parasites are indigenous species that have been attacking native weevils, but which now, in many instances, seem to be transferring their attention to the great enemy of the cotton plant. Since the control by these inimical insects can be aided by several distinct methods of practice, it is considered justifiable to present the following remarks:

The preliminary studies which have been necessary in order to perfect any methods of economic treatment have involved the collection and individual examination of infested cotton forms during 1906 and 1907 which have contained over 54,000 weevil stages, exclusive 